Rev. Tomasz STĘIEŃ*

\title{
THERE ARE TWO ROADS MARKED OUT TO US FOR THE DISCOVERY OF WHAT WE SEEK... EUNOMIUS' ARGUMENTS ON THE GENERATION OF THE SON BASED ON THE CONCEPTS OF SUBSTANCE AND ACTIVITY ${ }^{* *}$
}

\begin{abstract}
"There are two roads marked out to us for the discovery of what we seek"1. This sentence from Liber apologeticus by Eunomius opens the fragment recognized as being one of the most important in the entire treaty. Richard Paul Vaggione notices that "In some ways this might almost be taken as a summary of the contents of the treatise"2. Eunomius presents his theological methodology and his two ways could be described as deductive and inductive methods of reasoning ${ }^{3}$. Vaggione even proposes to recognize the entire structure of Liber apologeticus according to this fragment ${ }^{4}$. In my article, I would like to show the structure and content of his arguments in the context of the response of Eunomius' opponents - Basil the Great and Gregory of Nyssa. Since the deductive argument has already been widely commented on ${ }^{5}$, I would like to focus on the latter, which starts form the activity ${ }^{6}$ of begetting and an attempt to show the nature of the Unbegotten Father.
\end{abstract}

${ }^{*}$ Rev. dr hab. Tomasz Stępień, prof. UKSW - Chair of The Philosophy of Religion, Department of Theology, Cardinal Stefan Wyszyński University in Warsaw; e-mail: t.stepien@uksw.edu.pl.

** The author acknowledges financial support from the National Science Centre, Poland, grant number 2013/11/B/HS1/04140.

${ }^{1}$ Eunomius, Liber apologeticus 20, 5-6, ed. and transl. R.P. Vaggione, in: Eunomius, The Extant Works, Oxford 1987, 58.

${ }^{2}$ R.P. Vaggione, Introduction, in: Eunomius, The Extant Works, p. XII.

${ }^{3}$ R.P Vaggione (ibidem, p. XII) calls the methods of Eunomius "a priori and a posteriori" but since there is no sensual experience in the latter it seems to be more appropriate to call them deductive (from cause to effect) and inductive (from effect to cause).

${ }^{4}$ Cf. ibidem, p. XII.

${ }^{5}$ The key point in the deductive argument is Eunomius' claim that man can know the essence of God thanks to the unique name "unbegotten". This argument is based on the specific theory of names used by the Neo-Arian for this purpose, which was widely criticized by Basil the Great. Eunomius' theory of names and its critique was widely presented by M. DelCogliano, Basil of Caesarea's AntiEunomian Theory of Names, Leiden - Boston 2010, 25-48 and 153-187.

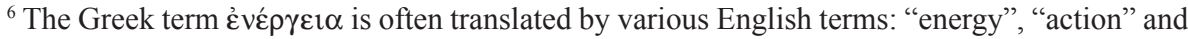
"activity". R.P. Vaggione in his translation uses the term "action" (eg. Eunomius, Liber apologeticus 
Eunomius declares what his theological methodology is by saying:

"There are two roads marked out to us for the discovery of what we seek - one is that by which we examine the actual essences and with clear and unadulterated reasoning about them make a judgement on each; the other is an enquiry by means of the actions, whereby we distinguish the essence on the basis of its products and completed works - and neither of the ways mentioned is able to bring out any apparent similarity of essence"7.

The clear goal of Eunomius is to demonstrate that there is no similarity of essence between the Father and the Son, by which he wants to support the Heteroousian position. The first way, which may be called deductive, depends on the knowledge of the essences of the Father and the Son. Eunomius claims that it is possible to make a study based on the essence as it is in itself ( $\kappa \alpha \theta^{\prime}$

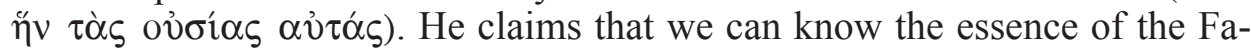
ther and the Son because they were revealed to us in the names Unbegotten ( $\alpha \gamma \dot{\varepsilon} v \vee \eta \tau o \varsigma)$ and Begotten $(\gamma \dot{\varepsilon} \vee v \eta \mu \alpha)$. Those are not merely names but rather pure concepts ( $\kappa \alpha \theta \alpha \rho$ òs $\lambda$ ó $\gamma \circ \varsigma$ ), and that is why they can bring true cognition of the essence. The name Unbegotten can be demonstrated simply by showing that the Father existed before all things. Eunomius does not claim that this is simply a name, but a name that reveals or even is the essence of the Father. Therefore, he repeats twice that unbegotten must mean the unbegotten essence

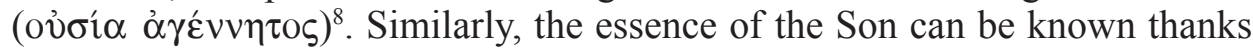
to the name Begotten. Eunomius feels more comfortable here, starting his argumentation with reference to the Holy Scripture which calls the Son of God

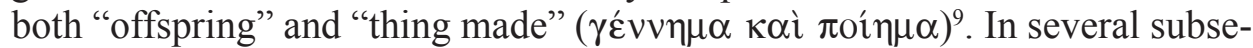
quent chapters, Eunomius explains how those two terms should be understood with regard to substance, because they signify the effect of the activity of the Father, which is begetting. Since in both cases of the Father and the Son the entire argumentation depends on names which should reveal essence, the core of counterarguments used by Basil the Great is directed against his understanding of the relation between name and essence ${ }^{10}$. In case of the essence of

20, 8, in: The Extant Works, p. 58). Mark DelCogliano and Andrew Radde-Gallwitz in their translation of Against Eunomius by Basil the Great propose to use "activity" (St. Basil of Caesarea, Against Eunomius, Washington D.C. 2011, 77). Giulio Maspero (Trinity and Man. Gregory of Nyssa "Ad

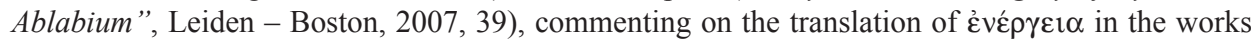
of Gregory of Nyssa, says: "Following Daniélou, it would seem that the best choice for translating

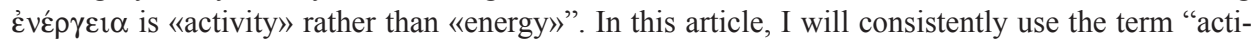
vity" apart from the direct quotations of R.P. Vaggione's translation of Eunomius' works.

${ }^{7}$ Eunomius, Liber apologeticus 20, 5-10, ed. and transl. Vaggione, p. 58-59.

${ }^{8} \mathrm{Cf}$. ibidem 7, 12, ed. and transl. Vaggione, p. 40: "the Unbegotten, or rather, that he is unbegot-

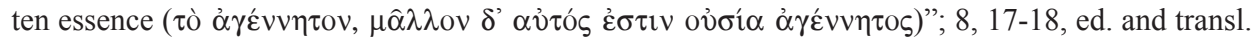

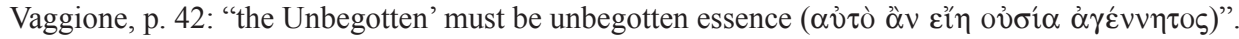

${ }^{9}$ Ibidem12, 1-3, ed. and transl. Vaggione, p. 46-48.

${ }^{10} \mathrm{Cf}$. DelCogiliano, Basil of Caesarea's Anti-Eunomian Theory of Names, p. 153-187. 
the Son the problem also lies in the quotation from the Book of Proverbs 8: 22, which has a different meaning in various Greek translations of the Old Testament. Because this fragment was frequently used by Arian writers it was also often commented by Basil the Great and Gregory of Nyssa ${ }^{11}$.

The second way, which is the main concern of this paper, can be called inductive since it begins with the activity which should reveal the essence. However, at the beginning, Eunomius underlines that those two ways are interdependent. The previous analysis of the pure concept of the essence of the Father showed that his essence is beyond any comparison with any other being. Since activity must be understood as conforming to the dignity of nature, it follows that the activities of the Father must also be incomparable with any other activity. Therefore, the activities as well as the substances of the Father and the Son must differ ${ }^{12}$. The opposite reasoning starts with the creations which are the effects of activity, and here Eunomius once again refers to Proverbs 8: 22 saying that the Son is "a thing made" $(\pi \circ i \eta \mu \alpha)$. Since he is something made and the Holy Spirit is the creation of the Son it follows that their activities must differ, and consequently one "accepts as indisputable the proof that their essences are distinct as well"13. Eunomius is sure that his reasoning is so obvious that he only mentions the differences between the acts of creation performed by the Father and the Son and the difference between the one who worships (the Son) and who is worshipped (the Father). In his eyes any property or description (essence, activity, authority, name) is so intrinsically linked with the being itself that ascribing the same properties to the Father and the Son unavoidably leads to speaking of "two Unbegottens" 14 .

Later on, Eunomius explains further how he understands the activity of God. One should avoid perceiving it as human activity, because it would mean that "activity is some kind of division or motion of his essence ( $\mu \varepsilon \rho \imath \sigma \mu$ òv

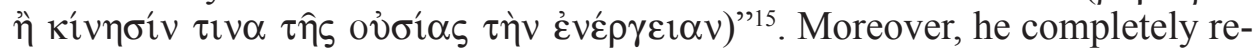
jects the notion that activity can be unified with the essence of God. Such "pagan sophistries" would mean making God coeval with the world ${ }^{16}$. Eunomius explains that since the essence of God is without the beginning and endless activity should also have the same features if it is the same with substance ${ }^{17}$.

${ }^{11}$ Cf. Basilius Caesariensis, Adversus Eunomium II 1, 20, ed. B. Sesboüé - G.M. de Durand - L. Doutreleau, SCh 305, Paris 1983, 12; Gregorius Nyssenus, Contra Eunomium I 299, ed. W. Jaeger, GNO 1, Leiden 1960, 114, 26 - 115, 11; ibidem III 1, 22-63, ed. W. Jaeger, GNO 2, Leiden 1960, $11,8-26,11$.

${ }^{12} \mathrm{Cf}$. Eunomius, Liber apologeticus 20, 12-16, ed. and transl. Vaggione, p. 58-60.

${ }^{13}$ Cf. ibidem 20, 18-19, ed. and transl. Vaggione, p. 60.

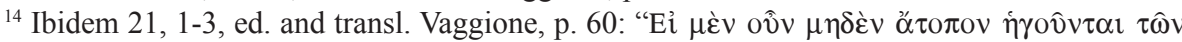

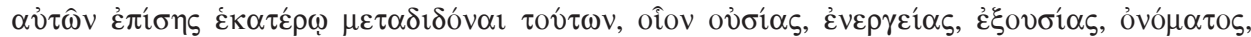

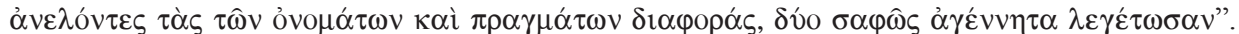

${ }^{15}$ Ibidem 22, 9, ed. and transl. Vaggione, p. 62-63.

${ }^{16}$ Cf. ibidem 22, 10-12, ed. and transl. Vaggione, p. 62.

${ }^{17} \mathrm{Cf}$. ibidem 23, 5-7, ed. and transl. Vaggione, p. 62. 
The result of such proposition could possibly lead only to two false conclusions: that the activity of God is ineffective, or its effect is also unbegotten ${ }^{18}$. This reasoning seems sound but I would like to note that Eunomius leaves some key premises unexplained. He argues that activity must have its beginning and its end to produce the effect, but he does not clarify how the infinite essence of God can be the foundation of the beginning of activity. In other words, if activity must begin at some point, how God who has no beginning can be the beginning of activity. Eunomius feels safe claiming that activity is not identical with essence, but such claim must result in the conclusion that God himself cannot have any internal activity. If so, how can one argue that he is living God, since life must be perceived as some kind of activity. To my mind Eunomius' reasoning results in the perception of God who is more similar to the Platonic idea - a completely lifeless but perfect paradigm - than the loving and living God who saves mankind. The solution would be to admit that the internal activity of God is totally incomprehensible and above human intellectual power, but this would be inconsistent with Eunomius's claim that we can have knowledge of the essence of God.

At this point, Eunomius rather surprisingly shifts from describing activity as such to the activity of will (ßov́ $\lambda \eta \sigma \imath v$ ) and says that the will is "the truest and most befitting God"19. The will of God is for Eunomius probably the most suitable demonstration because it can be described as instant, and the object willed by God comes to existence at the very moment in which he wills it. There is an obvious contrast between the eternal and unchanging essence of God and immediately effective act of will. If God creates by the act of his will it is obvious that the Son of God must also have been created this way. The Arian's reasoning concludes with the statement:

"Only-begotten exists by virtue of the will of the Father, then of necessity it is not with respect to the essence but with respect to the action (which is what the will is) that the Son preserves his similarity to the Father"20.

As we can see, the activity of God can be characterized as being intrinsically linked with his essence, but at the same time it cannot be one with the essence, so it must be external. Since, as he claimed, nothing can be similar to the Unbegotten essence, the Son is also not similar to the essence but rather similar to the activity of will. Thus, he is the first creation and must have a completely different essence than the Father. However, the example of will shows well another problem which remains unsolved. The act of will is simultaneously external and uncreated, and must be understood as something in between the Father and the Son who, on the contrary, is the creation. So the problem here lies in a clear distinction of the Creator and the creation, which

\footnotetext{
${ }^{18}$ Cf. ibidem 23, 10-12, ed. and transl. Vaggione, p. 64.

${ }^{19}$ Ibidem 23, 16-17, ed. and transl. Vaggione, p. 64-65.

${ }^{20}$ Ibidem 24, 2-4, ed. and transl. Vaggione, p. 65.
} 
becomes vague and impossible to recognize. If so, how can one claim that we can clearly perceive the Son of God as the first creation?

The last topic discussed by Eunomius is the understanding of the term "image" ascribed to the Son of God. His entire argumentation of this matter depends on the exegesis of a fragment from the Letter to the Colossians 1: 15-16, where the Son of God is called "the image of the invisible God, the first-born of all creation, because in him all things were created, in heaven and on earth, visible and invisible". Eunomius does not reject calling the Son of God with the name "image", but rather tries to explain how this name should be understood. According to him the expression "all things created with him" means that all things were created together with the Son, who is the first creation. Therefore, the Son is not the image of the essence of God but rather the image of the activity of God. Since such explanation seems a bit stretched he tries to elaborate by saying:

"The word «image», then, would refer the similarity back, not to the essence of God, but to the action unbegottenly stored up in his foreknowledge prior to the existence of the first-born and of the things created «in him»" 21 .

This explanation exposes deeper how Eunomius understands the relation between activity and essence. Activity reveals essence, and gives the knowledge on the essence of God because it is at first unbegottenly stored hidden

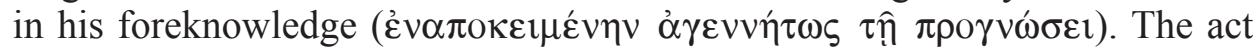
of creation is simply a confirmation of this foreknowledge which instantly happens thanks to the act of God's will. Although this argumentation seems to support the direct relation between essence and activity, it does not answer the question about the status of the external act of God's will. Moreover, Eunomius seems to realize that such explanation of Colossians 1: 15-16 adds unnecessary complication to the text. Therefore, he explains further trying to argue that in this text the term "Father" does not describe the essence of the Father but rather the act of his will, while the term "Son" refers to the essence of the Son of God. He concludes that any other interpretation would effect in admitting that there is no difference between the Father and the Son and in a confusion of not only their essences but also their names ${ }^{22}$.

In the next chapter, Eunomius tries to demonstrate that the Holy Spirit as the third person of the Trinity must also have a different essence. The demonstration is based on the premise that there is an order in nature. This or-

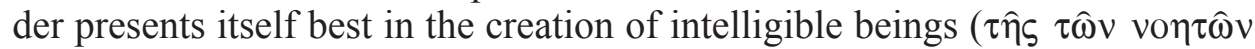

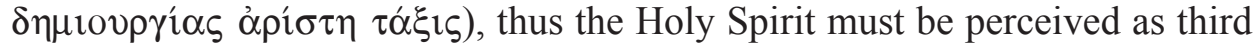
after the Father and the Son ${ }^{23}$. Since the Holy Spirit was created at the command of the Father by the activity of the Son, he lacks the power of creation,

\footnotetext{
${ }^{21}$ Ibidem 24, 10-13, ed. and transl. Vaggione, p. 65.

${ }^{22}$ Cf. ibidem 24, 18-28, ed. and transl. Vaggione, p. 66.

${ }^{23}$ Cf. ibidem 25, 10-12, ed. and transl. Vaggione, p. 66.
} 
but has the power of sanctifying and instructing what has been previously created $^{24}$. In my opinion, here the whole argumentation collapses because Eunomius cannot show any activity specific to the Holy Spirit which would reveal his nature in relation to the Father and the Son. He does not mention that sanctification or instruction can be treated as such activity. The Arian seems to realize that his argumentation is week at this point so he says at the end that the issue "requires a lengthy discourse"25.

Eunomius started his reasoning with a quotation from the Book of Proverbs, which shows that the Son is a creation made by the Father. It is so important because it names the effect of the activity of the Father and allows the entire second type of argumentation. Basil and Gregory rightly assumed that undermining the Greek translation of this passage of the Holy Scripture effectively dismantled Eunomius' argumentation. However, there is also another problem of the interrelationship between substance and activity. As we have seen, Eunomius firmly claims that these two are almost inseparable and thus we cannot consider substance without activity as well as activity without substance. The Arian gives only a vague explanation why it is so. Moreover, if this assumption is correct how is it possible to claim that activity which is so intrinsically linked with substance could be only something external.

In his critique, Basil the Great focuses on the problem of being greater and smaller in comparison between substance, activity and product. He argues that it leads to a contradiction if one claims that substance is greater than activity and activity greater than its effect. Activity must be proportional to the product and "from a great activity come great products, and from a small activity smaller products" ${ }^{\prime 26}$. Therefore, if Eunomius claims that activity is greater than a product the unavoidable conclusion is that the Father is unable to make the product equal to his activity ${ }^{27}$. Basil also criticized Eunomius' argumentation as to the title of Christ as an "image of God". He notices that when his opponent said: "its activity [activity of the substance] is consistent with and appropriate to its own dignity", he also admitted that unbegottenness is dignity. But unbegottenness is also the substance of the Father, so it follows that dignity must also be a substance. Basil then uses the simple reasoning that when $\mathrm{A}$ is $\mathrm{B}$ and $\mathrm{B}$ is $\mathrm{C}$ then $\mathrm{A}$ must also be $\mathrm{C}$. Then he goes further saying:

"The dignity, says Eunomius, is consistent with the substance of God; his activity is proportional to the dignity; the Only-Begotten is an image of the activity. And vice versa, if the Only-Begotten is an image of the activity, and

\footnotetext{
${ }^{24}$ Cf. ibidem 25, 23-26, ed. and transl. Vaggione, p. 68.

${ }^{25}$ Ibidem 25, 29, ed. and transl. Vaggione, p. 69.

${ }^{26}$ Basilius Caesariensis, Adversus Eunomium I 24, 18, ed. B. Sesboüé - G.M. de Durand - L. Doutreleau, SCh 299, Paris 1982, 258, transl. DelCogliano - Radde-Gallwitz, p. 125.

${ }^{27}$ Cf. ibidem I 24, 20-21, SCh 299, 258.
} 
the activity is an image of the dignity, and the dignity is an image of the substance, then the Only-Begotten will be an image of the substance" 28 .

Basil's argumentation shows that it is useless to multiply the names and attributes of God, because the conclusion is unavoidable: the Son is the image of the substance of the Father, not the image of the activity.

The critique of Gregory of Nyssa is even more interesting as he attacks the very understanding of the relationship between substance and activity used by Eunomius. In his Second Apology the Neo-Arian writer simply repeats his main view of the methodology of the entire argumentation ${ }^{29}$ and Gregory quotes this entire fragment calling it the "system of blasphemy":

"Our whole doctrine is summed up in the highest and principal essence, in the essence which exists through it but before all others, and in the essence which is third in terms of origin and the activity which produced it. This same order is revealed whether we consider the essences themselves or approach them through their characteristic activities" 30 .

Once again Eunomius repeats two types of reasoning starting from the essence and starting from activities. He also confirms that "activities are defined at the same time as their works, and the works match the activities of those who effected them" 31 . What seems to be new is that Eunomius apparently tries to combine those two methods saying that doubts about activities should be resolved with reference to essences, and doubts about essence in reference to primary activities ${ }^{32}$. This suggests that Basil's critique somehow undermined Eunomius reasoning and now he does not see essence and activity in itself as clearly conceivable. Therefore, activity and essence should be considered in relation to each other. Essence somehow defines activity, but also activity defines and reveals essence.

Gregory of Nyssa points out in his critique that Eunomius did not explain in what sense activity accompanies substance. Clearly it is not activity which comes from nature, like combustion accompanying fire, because that would mean that God as substance has accidents ${ }^{33}$. To claim that the Son of God is a creation he must have come to existence thanks to a free act of will of the Father. Eunomius says that this act is voluntary and at the same time it necessarily accompanies substance like external consequence ${ }^{34}$. Gregory sees

${ }^{28}$ Ibidem II 31, SCh 305, 130, transl. DelCogliano - Radde-Gallwitz, p. 179.

${ }^{29}$ Cf. Gregorius Nyssenus, Contra Eunomium I 151-154, GNO 2, 71, 28 - 73, 15.

${ }^{30}$ Ibidem I 151, GNO 1, 71, 28 - 72, 7, transl. S.G. Hall, A refutation of the first book of the two published by Eunomius after the decease of holy Basil, in: El "Contra Eunomium I" en la produccion literaria de Gregorio de Nisa, ed. L.F. Mateo-Seco - J.L. Bastero, Pamplona 1988, 57.

${ }^{31}$ Ibidem I 152, GNO 1, 72, 12-15, transl. Hall, p. 57.

${ }^{32} \mathrm{Cf}$. ibidem I 154, GNO 1, 73, 3-15.

${ }^{33} \mathrm{Cf}$. ibidem I 208, GNO 1, 87, 9-19.

${ }^{34}$ Cf. ibidem I 209, GNO 1, 87, 19 - 88, 3. 
a clear contradiction here. Moreover, he says that normally in the common language nobody says that activity accompanies substance. Activity must always be perceived as being dependent on substance, and always perceived along with it, like a person who is described as active at metalwork: such description contains both substance (person) and its activity (metalworking) ${ }^{35}$. Eunomius' claims would not only divide what is normally perceived as joined, but also would introduce activity as a separate being between the Father and the Son ${ }^{36}$. The problem multiplies in the case of the Holy Spirit, because there has to be also another activity between the Son and the Holy Spirit which is neither the Son nor the Holy Spirit ${ }^{37}$.

The main problem of Eunomius is then understanding activity as some kind of independent being. To refute such claim Gregory must have properly defined how the substance produces activity and also how activity reveals the substance. First, he explains that activity in its existence is intrinsically linked with substance and he does that by using the preposition $\pi \varepsilon \rho$ í with accusative (not genitive) ${ }^{38}$. Moreover, he uses the definition of activity as a "movement

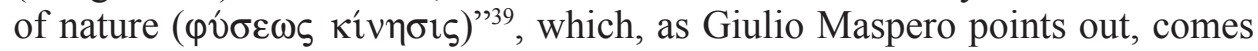
from Aristotle De genratione animalium ${ }^{40}$. Commenting on the development of an embryo Aristotle says that any product of nature or art can must originate from something that is in act. Therefore, activity as such cannot create anything because it has no independent being - it is always the activity of nature $^{41}$. What is significant, in this fragment Aristotle uses the example of making a sword which is similar to Gregory's image of a metalworker, which also shows that metalworking as activity cannot be perceived as separated from the person who performs such activity ${ }^{42}$. Aristotle more precisely explains that "heat and cold may make the iron soft and hard, but what makes a sword is the movement of the tools employed, this movement containing the principle of the art" ${ }^{\prime \prime 3}$. Activity, then, as an accident which is the movement of nature must be described always with this nature, because if we see it independently we cannot explain the effect it produces. It is probable that Eunomius could not see this issue clearly because in his definition activity is (as we have seen

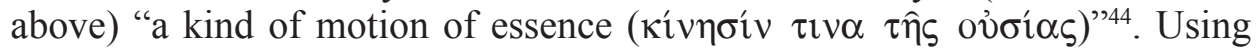

\footnotetext{
${ }^{35}$ Cf. ibidem I 210, GNO 1, 88, 4-9.

${ }^{36} \mathrm{Cf}$. ibidem I 211, GNO 1, 88, 9-17.

${ }^{37}$ Cf. ibidem I 247-249, GNO 1, 99, 8-24.

${ }^{38}$ See the G. Maspero's (Trinity and man, p. 38-39) discussion about using $\pi \varepsilon \rho i$ with accusative.

${ }^{39}$ Gregorius Nyssenus, Contra Eunomium I 211, GNO 1, 88, 15.

${ }^{40} \mathrm{Cf}$. Maspero, Trinity and man, p. 41.

${ }^{41}$ Cf. Aristoteles, De generatione animalium II 1, 735a, ed. P. Louis: Aristote, De la Génération des Animaux, Paris 1961, 56.

${ }^{42}$ Cf. Gregorius Nyssenus, Contra Eunomium I 210-211, GNO 1, 88, 4-17.

${ }^{43}$ Aristoteles, De generatione animalium II 1, 734b-735a, ed. Louis, p. 55, transl. J. Barnes, in: Aristotle, The Complete Works of Aristotle, Princeton 1991, 1598 (electronic edition).

${ }^{44}$ Eunomius, Liber apologeticus 22, 9, ed. and transl. Vaggione, p. 62.
} 
"substance" instead of "nature" could make the understanding of the intrinsic bondage of activity with its subject difficult.

It is clear that separating activity of the Father from the Father himself Eunomius could not explain how activity can give us the knowledge of essence. Gregory mercilessly points out that difficulty in commenting Eunomius' claim that "same activities produce identical works" 45 . Gregory uses the examples of fire, Sun and food to show that the same activity produces various effects ${ }^{46}$. Fire causes that metals melt, clay hardens, wax liquefies, etc. Fire is like the Sun, which also has one activity producing various effects. Food accepted in the mouth nourishes various organs. As a last example Gregory gives the action of the hand which can produce works of art as well as killing people at war or cultivating soil ${ }^{47}$. Moreover, if Eunomius' claim would be true, it would have supported the orthodox position. Since the action of the Son's will is the same as the action of the Father according to the Scripture (Jn 5: 19), we cannot assume that there is any difference between their substances ${ }^{48}$.

Another problem which Gregory sees in the quoted text is the perception of the sequence of creation. It is odd to say that creation must take place in such a sequence and to show it Gregory gives an example: "who would be prepared to say that the sky being God's work, the sun is the sky's, the moon is the sun's, the stars are the moons, and anything else is creation is theirs?"49 Such an order cannot be observed even in generation of living beings, because one generates the other of the same species. It is no use to say that creation is different in case of spiritual beings because they have an intimate connection of the same nature so Eunomius" demonstration means "resisting the principle of nature" 50 .

We can summarize by saying that Gregory of Nyssa strongly opposes the division between substance and activity which was never clearly explained by Eunomius. He rightly assumes that activity which is not substantial cannot be intrinsically connected with substance. To defend his position Eunomius must explain that activity cannot be identified with the substance. He even accused his opponents that such identification is of Hellenic influence ${ }^{51}$. Therefore, activity cannot define or show what substance is and vice versa - substance cannot

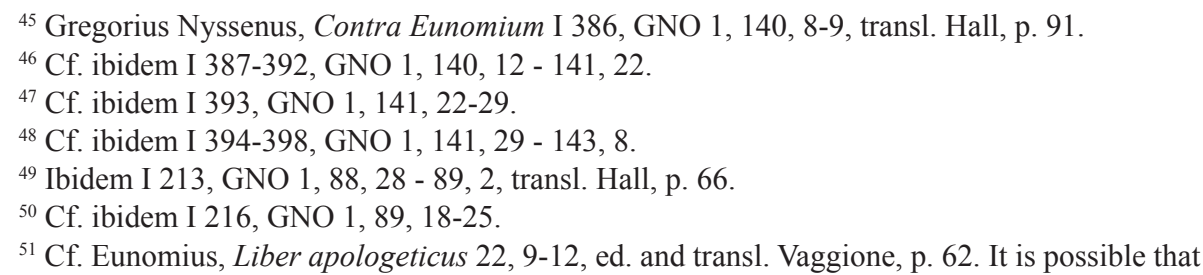
Eunomius refers here to the doctrine of Plotinus who in his discussion on the supreme genres opposed the peripatetic position. He identifies the supreme genres of Plato's Sophist with the activity of intellectual substance (A.C. Lloyd, Anatomy of Neoplatonism, Oxford 1990, 85-95). One of the key doctrines of Plotinus was also understanding procession of hypostases as double activity, in which the first activity was described as internal activity of the substance (D. Bradshaw, Aristotle East and West. Metaphysics and the Division of Christendom, Cambridge 2004, 73-96). 
define its external activity. For Gregory, then, both methods of reasoning proposed by Eunomius are unclear and unjustified because in both cases he does not start with a premise based on a clear concept. So he questions the methodology as lacking in basic logic ${ }^{52}$. He simply explains ignotum per ignotum. Moreover, we can also see another unexplained contradiction which Gregory sees in the reasoning of his opponent. Eunomius claims that the essences of the Father and the Son are clearly and simply perceivable but arguing on it he makes the claims which are contrary to the common perception of the entire nature. We can conceive the essences of divine persons exactly like any other essences, but their activities must be perceived in a completely different way. While the activities of the divine persons have to be separated from their essence, in any other case activity is inseparable from substance. In the case of the Father generation produces different essence or nature, but in every other being generation produces an effect of the same nature. Finally, the creation of the Son and the Holy Spirit took place sequentially but we cannot observe such sequence in the creation of the universe.

\section{(Summary)}

Eunomius of Cyzicus in his writings defends Arian understanding of the generation of the Son of God. He claims that the generation must be perceived as creation of the new essence. Therefore, the Son of God is the first creation and could not be equal with the Father. Among many arguments that he gives to support his thesis, he also evokes the distinction between essence (ov $\sigma^{\prime} \alpha$ ) and activi-

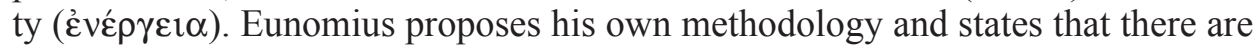
two ways leading to proper understanding of generation. First one leads form the recognizing of the essence of God to conclusions on the generation, which is the activity of the Father. Another way of demonstration starts from the activities and allows distinguishing essences according to the products that they have caused. Eunomius underlines that both ways of enquiry lead to an irrefutable conclusion that the Father and the Son cannot have the same essence. Moreover, he claims that there could be no likeness between the two essences of the Father and the Son.

The goal of this article is to review Eunomius' arguments from the viewpoint of their effectiveness and proposed methodology. The orthodox answer of Basil the Great and Gregory of Nyssa are the context of reviewing NeoArian claims.

\footnotetext{
${ }^{52}$ Cf. Gregorius Nyssenus, Contra Eunomium I 217-219, GNO 1, 90, 1-19.
} 


\section{SA DWIE DROGI ODKRYCIA TEGO, CZEGO POSZUKUJEMY... ARGUMENTY EUNOMIUSZA DOTYCZAॄCE ZRODZENIA SYNA BOŻEGO OPARTE NA POJECCIACH SUBSTANCJI I DZIAŁANIA}

\section{(Streszczenie)}

Eunomiusz z Kyziku w swoich pismach broni neoariańskiego rozumienia pochodzenia Syna Bożego twierdząc, że musi być ono postrzegane jako stworzenie nowej substancji. Syn Boży jako stworzenie nie może więc być równy Bogu Ojcu. Pośród argumentów, które przytacza centralne miejsce zajmuje rozróżnienie po-

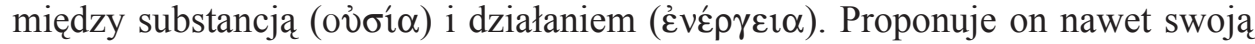
metodologię badań teologicznych twierdząc, że są dwie drogi, które prowadzą do właściwego rozumienia zrodzenia Syna. Pierwsza z niech prowadzi od poznania istoty Boga do ustalenia natury pochodzenia Syna, zaś punktem wyjścia drugiej jest samo zrodzenie Syna Bożego, które jest działaniem Ojca i ma doprowadzić do właściwego rozumienia boskiej istoty. Według Eunomiusza obydwie drogi prowadzą w sposób konieczny do konkluzji, że Ojciec i Syn nie mogą posiadać tej samej substancji oraz że te dwie substancje nie mogą być do siebie podobne.

Celem niniejszego artykułu jest prześledzenie argumentów Eunomiusza w aspekcie ich spójności i proponowanej przez niego metodologii. Jako punkt odniesienia służy odpowiedź sformułowana przez jego dwóch wielkich przeciwników Bazylego Wielkiego i Grzegorza z Nyssy.

Key words: Eunomius, Basil the Great, Gregory of Nyssa, substance, energy, activity.

Słowa kluczowe: Eunomiusz, Bazyli Wielki, Grzegorz z Nyssy, substancja, energia, działanie.

\section{BIBLIOGRAPHY}

\section{Sources}

Aristoteles, De generatione animalium, ed. P. Louis: Aristote, De la Génération des Animaux, Paris 1961, transl. J. Barnes, in: Aristotle, The Complete Works of Aristotle, Princeton 1991, 1561-1691.

Basilius Caesariensis, Adversus Eunomium, ed. B. Sesboüé - G.M. du Durand - L. Doutreleau, vol. 1, SCh 299, Paris 1982, vol. 2, SCh 305, Paris 1983, transl. M. DelCogliano - A. Radde-Gallwitz: St. Basil of Caesarea, Against Eunomius, Washington D.C. 2011.

Eunomius, Liber Apologeticus, ed. and transl. R.P. Vaggione, in: Eunomius, The Extant Works, Oxford 1987, 34-74.

Eunomius, Liber Apologeticus, ed. B. Sesboüé - G.M. du Durand - L. Doutreleau, in: Basile de Césarée, Contre Eunome, Paris 1983, 234-298.

Gregorius Nyssenus, Contra Eunomium, GNO 1-2, ed. W. Jaeger, Leiden 1960, transl. S.G. Hall, A refutation of the first book of the two published by Eunomius after the 
decease of holy Basil, in: El "Contra Eunomium I" en la produccion literaria de Gregorio de Nisa, ed. L.F. Mateo-Seco - J.L. Bastero, Pamplona 1988, 35-135.

Literature

Bradshaw D., Aristotle East and West. Metaphysics and the Division of Christendom, Cambridge 2004.

DelCogliano M., Basil of Caesarea's Anti-Eunomian Teory of Names, Leiden - Boston 2010.

DelCogliano M. - Radde-Gallwitz A., Introduction, in: St. Basil of Caesarea, Against Eunomius, Washington D.C. 2011, 3-78.

Lloyd A.C., Anatomy of Neoplatonism, Oxford 1990.

Maspero G., Trinity and Man. Gregory of Nyssa “Ad Ablabium”, Leiden - Boston 2007.

AgGione R.P., Introduction, in: Eunomius, The Extant Works, Oxford 1987, XII-XVII. 